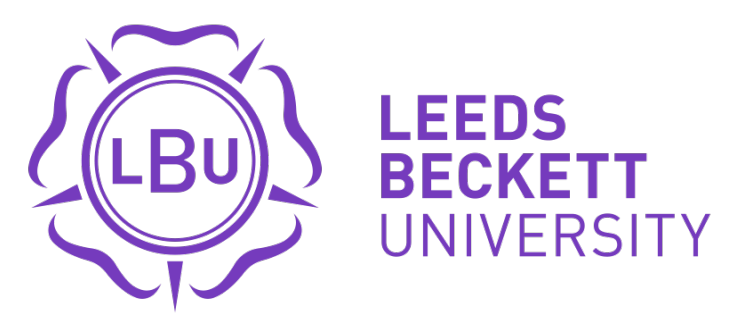

Citation:

O'Reilly, MF (2016) Peace and Justice through a Feminist Lens: Gender Justice and the Women's Court for the Former Yugoslavia. Journal of Intervention and Statebuilding, 10 (3). pp. 419-445. ISSN 1750-2977 DOI: https://doi.org/10.1080/17502977.2016.1199482

Link to Leeds Beckett Repository record:

https://eprints.leedsbeckett.ac.uk/id/eprint/8082/

Document Version:

Article (Accepted Version)

This is an Accepted Manuscript of an article published by Taylor \& Francis in Journal of Intervention and Statebuilding on 31st August 2016, available online: http://doi.org/10.1080/17502977.2016.1199482

The aim of the Leeds Beckett Repository is to provide open access to our research, as required by funder policies and permitted by publishers and copyright law.

The Leeds Beckett repository holds a wide range of publications, each of which has been checked for copyright and the relevant embargo period has been applied by the Research Services team.

We operate on a standard take-down policy. If you are the author or publisher of an output and you would like it removed from the repository, please contact us and we will investigate on a case-by-case basis.

Each thesis in the repository has been cleared where necessary by the author for third party copyright. If you would like a thesis to be removed from the repository or believe there is an issue with copyright, please contact us on openaccess@leedsbeckett.ac.uk and we will investigate on a case-by-case basis. 


\title{
Peace and Justice through a Feminist Lens: Gender Justice and the Women's Court for the Former Yugoslavia
}

\author{
Maria O'Reilly
}

ABSTRACT

KEYWORDS

Post-conflict interventions to 'deal with' violent pasts have moved feminism; gender justice; from exception to global norm. Early efforts to achieve peace and international; local; Nancy justice were critiqued as 'gender-blind'-for failing to address sexual and gender-based violence, and neglecting the gender- specific interests and needs of women in transitional settings. The advent of UN Security Council resolutions on 'Women, Peace and Security' provided a key policy framework for integrating both women and gender issues into transitional justice processes and mechanisms. Despite this, gender justice and equality in (post-) conflict settings remain largely unachieved. This article explores efforts to attain gender-just peace in post-conflict Bosnia and Herzegovina (BiH). It critically examines the significance of a recent 'bottom-up' truthtelling project - the Women's Court for the former Yugoslavia - as a locally engaged approach to achieving justice and redress for women impacted by armed conflict. Drawing on participant observation, documentary analysis, and interviews with women activists, the article evaluates the successes and shortcomings of responding to gendered forms of wartime violence through truth-telling. Extending Nancy Fraser's tripartite model of justice to peacebuilding contexts, the article advances notions of recognition, redistribution and representation as crucial components of gender-just peace. It argues that recognizing women as victims and survivors of conflict, achieving a gender-equitable distribution of material and symbolic resources, and enabling women to participate as agents of transitional justice processes are all essential for transforming the structural inequalities that enable gender violence and discrimination to materialize before, during, and after conflict. 


\section{Introduction}

After the Cold War, the introduction of transitional justice (TJ) processes to 'deal with' violent pasts has moved from exception to global norm (Teitel 2003, 71). Through the deployment of judicial and non-judicial mechanisms - criminal trials, truth-telling initiatives, reparation programmes, institutional reform, etc.--societies attempt to come to terms with legacies of mass violence and abuse. In parallel, the importance of integrating both women and gender into peacebuilding and justice initiatives is increasingly stressed by international, regional and national actors. The adoption of UN Security Council Resolution 1325 (UNSCR 1325) in 2000 is hailed as a 'landmark' in this regard, placing gender equality on the UN's peace and security agenda for the first time (Cohn 2008). UNSCR 1325 and subsequent resolutions on 'Women, Peace and Security' (WPS) ${ }^{1}$ form a key policy framework for incorporating women's rights and gender issues into contemporary peace-building practices. These resolutions recognize the gendered impact of conflict, and stress the importance of integrating a gender perspective into peacebuilding. They call for women's full participation as active agents of peacebuilding, and affirm the need to respond to sexual and gender-based violence (SGBV) in conflict by providing survivors with access to justice, protection and redress. ${ }^{2}$

Fifteen years since UNSCR 1325, gender justice and equality is far from being achieved. Women are routinely side-lined from official peace processes (Bell and O'Rourke 2010); gender equality is rarely prioritized in peace agreements (Anderson 2012) and post-conflict reconstruction programmes (Aroussi 2011); and wartime gender violence is often not adequately addressed in TJ processes (Ní Aoláin and O'Rourke 2010; Buckley-Zistel and Stanley 2012). There is often no 'aftermath' of conflict for women (Meintjes, Pillay, and Turshen 2001). A 'gendered peace' frequently emerges (Pankhurst 2008), in which gendered, racialized, sexualized and classed power structures are often (re)inscribed (Pratt 2013). For these reasons, there is a pressing need to find new ways to challenge gendered hierarchies and norms in the transition from war to peace. Truth recovery mechanisms are increasingly advocated as a useful alternative or complement to criminal trials (e.g. Mertus 2004, 124). ${ }^{3}$ Truth commissions hold potential to transform gender relations and generate 'changes in existing laws and patterns of behavior that have contributed to inequality and discrimination' (World Bank, cited in Valji 2007, 15). They can provide victims a public platform to voice their experiences, and often consider a 'broad array of testimonies when analyzing and describing the greater pattern of abuse' (Hayner 2002, 28). Whilst early truth commissions were largely 'gender blind', more recent initiatives have incorporated women and gender into truth recovery processes (Theidon 2007, 457; Valji 2010, 9-13). ${ }^{4}$ Informal truth-telling initiatives are increasingly deployed by grassroots women's organizations to challenge and reinterpret dominant conceptions of justice promulgated by formal justice institutions, in ways that acknowledge and respond to the gendered harms of conflict, and respond to women's situated interests and needs (e.g. Chinkin 2006; Crosby and Lykes 2011; Kumar 2001; Reilly and Posluszny 2005). ${ }^{5}$ Despite their increasing popularity, there remains a scarcity of research on the successes and short-comings of these alternative/complementary forms of truth-telling, and the extent to which they deliver gender-just peace for women in (post-)conflict settings. Furthermore, 'gender justice' vis-àvis war and peace remains poorly conceptualized, with scholars often failing to differentiate gender justice from other concepts such as gender equality and women's empowerment (Goetz 2007, 17). ${ }^{6}$

Against this background, this article explores efforts to achieve gender justice in postconflict Bosnia and Herzegovina $(\mathrm{BiH}){ }^{7}$ In particular, it examines the significance of a recent feminist truth-telling initiative - the Women's Court for the former Yugoslavia — as a locally engaged approach to achieving justice for women affected by armed conflict and post-war 
reconstruction processes. The paper extends Nancy Fraser's (1997, 2003, 2005, 2008) tripartite model of justice to peacebuilding contexts, and foregrounds notions of recognition, redistribution and representation as crucial components of 'gender just' peace. This framework offers a powerful lens to interrogate competing visions of justice being articulated within sites of international peace and security interventions. It enables the 'dynamics of contestation' (Arnould 2016) surrounding top-down/international/elite-driven versus bottom-up/local/everyday justice processes to be exposed. In particular, this model brings into focus actors and issues, such as war-affected women and socio-economic justice which remain unrecognized or marginalized from dominant modes of peacebuilding (see also Lai 2016; Martin 2016). Significantly, Fraser's framework provides principles, concepts and strategies that are crucial for the design and implementation of effective post-war gender justice initiatives - enabling scholars and practitioners to identify, address and potentially transform the gendered structures of inequality that enable violence and discrimination to materialize before, during and after conflict.

The article begins by introducing Fraser's three-dimensional framework, and highlights her concepts of recognition, redistribution and representation as essential elements of gender justice. Next, the article deploys this framework to examine whether and how gender justice has been achieved for women in $\mathrm{BiH}$. It provides a short overview of the gender dynamics of war-fighting and peacebuilding, and examines the successes and failures of 'top-down' justice mechanisms implemented in this setting from a feminist perspective. It then examines in detail the achievements and limitations of the Women's Court as a 'bottom-up', 'grassroots' justice mechanism (versus 'top-down', 'elite-driven' justice processes) within the $\mathrm{BiH}$ context. Overall it is argued that the initiative has contributed to the recognition and representation of $\mathrm{BiH}$ women as victims/survivors of gendered violence and discrimination, and also added weight to demands for redistributive justice. Nevertheless, the Women's Court was hampered by a number of shortcomings which impeded recognition and participation of some survivors, and redistribution of material resources. Furthermore, its 'bottom-up' nature and focus on the micro-level means it will struggle to ensure that its efforts 'trickle up' to achieve transformative change at the macro-level.

\section{Note on methodology and scope}

The article draws mainly on data gathered from my observation of the Women's Court, which I attended in May 2015 and documented using detailed field notes, photographs and informal conversations with participants, activists and audience members. In addition, I draw on data gathered from over six years of research on gender and TJ processes in $\mathrm{BiH}$. Between 2011 and 2015, I undertook a total of 15 months' fieldwork in $\mathrm{BiH}$, interviewing activists from three types of organizations that campaign on gendered TJ issues: (i) associations of families of missing and killed persons; (ii) associations comprising former camp detainees, and victims/survivors of wartime torture, rape and sexual violence; and (iii) women's/feminist advocacy nongovernmental organizations (NGOs). ${ }^{8}$ My focus on $\mathrm{BiH}$ resulted in extensive explorations of activists' actions and interpretations; yet also limits the scope of the article to the $\mathrm{BiH}$ context rather than the wider region of ex-Yugoslavia. The article focuses on the Women's Court as a public performance, recognizing that the initiative instigated a process of truth-telling that is ongoing, though largely in private/semi-public forums. ${ }^{9}$

\section{Conceptualizing gender justice: recognition, redistribution and representation}


The transition from war to peace is often regarded as a unique 'window of opportunity' to pursue gender justice (Valji 2010). By challenging political, socio-economic and cultural inequalities, rather than restoring the problematic status quo ante, TJ processes may provide opportunities to unsettle rather than reinforce pre-existing gender hierarchies and norms (Rubio-Marín and de Greiff 2007, 325). These processes can confront underlying structural inequalities that preceded, contributed to and frequently persist post-conflict (Durbach and Chappell 2014, 548; Rubio-Marín 2009, 117), enabling gender-just forms of peace to be (re)built. Feminist scholars note that post-conflict gender justice requires an adequate conceptualization of the harms that are in need of remedy, and the design and implementation of appropriate procedures and practices of rendering justice (Campbell 2007). The particular mechanisms put in place must be sensitive to context and to the intersections between gender and other structures of power such as ethnicity/race, class, sexuality, (dis)ability etc. (Durbach and Chappell 2014, 548; Leatherman 2011,67) through which status disparities are constructed yet potentially transformed. Visions of gender justice are 'integrally tied' to broader, bottom-up campaigns to promote women's human rights, and to a praxis of solidarity across difference (Reilly 2007, 157). They also place women at the centre of TJ discourses and practices - as victims and survivors but crucially also as agents of post-war justice and peacebuilding processes (Ní Aoláin 2012).

Notwithstanding these valuable insights, the notion of gender justice is under-theorized in the current literature, and is variously deployed to describe a wide array of practices ranging from the equal participation of women in justice institutions through to targeted remedies for gender-based harms. ${ }^{10}$ Nancy Fraser's trivalent model of justice offers a promising framework for conceptualizing and evaluating gender justice policies and practices in (post-)conflict settings. Fraser's framework provides scholars and practitioners with a powerful conceptual toolkit for identifying and evaluating the gender justice concerns and needs of conflict-affected groups; detecting and responding to disparities and omissions in gender justice provision; and developing appropriate guidelines for achieving positive peace in the aftermath of conflict.

For Fraser $(2008,16)$, justice should be understood as 'parity of participation', which entails the construction of 'social arrangements that permit all to participate as peers in social life'. Participatory parity depends on two conditions: the 'objective condition' of a distribution of material resources that ensures 'participants' independence and voice'; and the 'intersubjective condition' of 'institutionalised patterns of cultural value [which] express equal respect ... and ensure equal opportunity for achieving social esteem' (Fraser 2003, 36). Fraser identifies three interconnected forms of injustice, which represent institutionalised obstacles that prevent some people from participating ... as full partners in social interaction' (Fraser 2003, 36). The first is cultural/symbolic injustice, which springs from negative forms of social representation, non-recognition and disrespect of particular individuals and groups (Fraser 1997, 14). The second is socio-economic injustice, resulting from the maldistribution of material resources due to the political-economic structure of society' and includes forms of exploitation, economic marginalization and deprivation (Fraser 1997, 13; see also Lai 2016). The third is participatory or representational injustice, which is rooted in political marginalization and the exclusion of specific individuals and groups from decision-making processes and institutions (Fraser 2005, 7).

SGBV in conflict can be viewed as both product and productive of all three forms of inequality. ${ }^{11}$ Regarding cultural/symbolic inequality, sexual violence is often enabled by gendered narratives that mark women's bodies as territory to be 'protected' by men of their 'own side', and attacked and conquered by the 'enemy' (Korač 2006, 513). Rape may be misrecognized as an unfortunate 'by-product' of war rather than a serious human rights violation (Buss 2009). Furthermore, social stigma is often wrongly ascribed to survivors 
(rather than perpetrators) due to gender-biased social/cultural values and norms that diminish their social status (Askin 2001). Concerning socio-economic injustice, structural inequalities enable and exacerbate SGBV-sexual violence is often perpetrated to extract material resources or 'compensate' soldiers otherwise excluded from economic spoils of war (True 2012, 121-122); whilst female relatives of persons missing/killed in conflict may endure poverty, discrimination and exploitation after assuming the traditionally masculine role of head-of-household (Dewhirst and Kapur 2015, 6). Regarding participatory or representational injustice, gender inequality in political, economic and social life is associated with higher levels of armed conflict within a state (Melander 2005; Caprioli 2005). Furthermore, survivors of wartime violence may be unable to participate in TJ processes and institutions, due for example to their devalued identities, compromised capacity to advance justice claims and barriers presented by institutional structures (Stanley 2009, 48).

In response to these injustices, Fraser advocates three intersecting types of remedies. First, she promotes recognition through 'revaluing disrespected identities and the cultural products of maligned groups', 'recognizing and positively valorizing cultural diversity', and transforming 'societal patterns of representation, interpretation and communication' (Fraser 1997, 19). Second, Fraser endorses redistribution through 'redistributing income, reorganizing the division of labor' and increasing democratic decision-making to overcome the injustices of maldistribution $(1997,19)$. Third, she highlights the importance of representation, both in terms of the boundaries involved in advancing claims to just distribution and reciprocal recognition, and the decision-making rules and procedures by which claims are adjudicated (Fraser 2005, 7). In relation to these, Fraser identifies two contrasting approaches - affirmation and transformation-to remedying injustice:

By affirmative remedies for injustice I mean remedies aimed at correcting inequitable outcomes of social arrangements without disturbing the underlying framework that generates them. By transformative remedies, in contrast, I mean remedies aimed at correcting inequitable outcomes precisely by restructuring the underlying generative framework. (Fraser 1997, 23)

Affirmative recognition entails acknowledging and upwardly revaluing the identities of marginalized groups, 'while leaving intact both the contents of those identities and the group differentiations that underlie them' (Fraser 1997, 24). In transitional settings, this may involve the acknowledgement of survivors of conflict-related sexual violence, for example, as a discrete category and equal in status to other war-affected groups. Affirmative redistribution entails reallocating goods more equitably within the existing socio-economic system (Fraser 2005, 87). This could entail implementing reparative measures such as property restitution, compensation for harms incurred, and rehabilitation through access to healthcare, without altering underlying relations of production.

Affirmative remedies have significant shortcomings however. Affirmative recognition strengthens group differentiation and promotes reification (Fraser 1997, 24). Affirmative redistribution primarily addresses the impact rather than roots of maldistribution $(1997,23)$ and is unable to 'challenge the deep structures that generate class disadvantage' $(1997,25)$. It may also result in 'injustices of recognition' by stigmatizing marginalized groups and marking 'the most disadvantaged as inherently deficient and insatiable' (1997, 25). Consequently, Fraser $(1997,27)$ favours the use of transformative approaches to achieve gender justice. These entail deep restructuring of relations of recognition and of production, rather than surface reallocations of respect and goods to existing identities and groups. Transformative recognition involves changing the 'underlying cultural-valuational structure' of identities via practices of deconstruction $(1997,24)$. This destabilizes collective identities in favour of 'multiple, debinarized, fluid, ever-shifting differences' (1997, 24). In (post-) conflict settings, this could entail deconstructing essentialized identity categories and polarized interpretations of violent pasts. Transformative redistribution entails transforming 
the underlying division of labour that causes socio-economic inequalities to arise $(1997,23)$. It may also 'promote solidarity, helping to redress some forms of misrecognition' (1997, 25-26). For Fraser $(2000,22)$, this requires supplanting neo-liberal economics with social democracy or democratic socialism.

Following Fraser, truth-telling and other TJ mechanisms can potentially achieve gender justice by providing recognition of women as victims/survivors of violence, achieving the redistribution of material and/or symbolic resources in a more gender-equitable manner, and enabling women to participate and voice their aspirations, needs and concerns as agents of post-war peacebuilding processes. In particular, they can challenge the 'status subordination' (Fraser 2003, 50) affecting many survivors by positively revaluing their identities (Fraser 1997, 15), challenging structural inequalities, redistributing wealth and resources, and enabling women's full and meaningful participation in post-war justice and peacebuilding processes $(1997,15)$. The remainder of this paper deploys Fraser's framework to evaluate gender justice initiatives in post-conflict $\mathrm{BiH}$.

\section{Background: gender, war and peacebuilding in $\mathrm{BiH}$}

War and post-war peacebuilding interventions provide the context within which gender justice initiatives have emerged in $\mathrm{BiH}$. The 1992-1995 war in $\mathrm{BiH}$ was rooted in the fall of Communism and the ethno-nationalist break-up of the Socialist Federal Republic of Yugoslavia (SFRY) following a series of economic and political crises. ${ }^{12}$ The build-up and outbreak of conflict was marked by the mobilization of ethno-national identities to attract support and spread fear and insecurity (Oberschall 2000). The manipulation of gender roles and identities was also crucial. Nationalist discourses constructed women as symbols of the nation, guardians of children and markers of national identity and honour (Bracewell 1996; Drakulić 1993; Mostov 2002). Men, in contrast, were represented in virile, heroic and militarized terms as warriors and saviours of the nation (Mostov 2002). Rape and sexual violence against women was widespread - all warring factions committed these crimes, yet the majority of victims were identified as Bosnian Muslim, and perpetrators Bosnian Serb, with Serb forces found to have deployed rape systematically as a tool of 'ethnic cleansing' (UN Security Council 1994). Men represent the vast majority of those killed and/or missing87 per cent of persons unaccounted for post-conflict were men mostly of military age (ICMP 2014).

War officially ended with the signing of the Dayton Peace Accords (DPA) in 1995. This incorporated all aspects of a traditional peace agreement, and also included the $\mathrm{BiH}$ Constitution and expansive remits for international organizations to reconstruct the $\mathrm{BiH}$ state (Cousens and Cater 2001, 33). Peace negotiations provided an opportunity for democracy, citizenship and peace to be 'reimagined' in gender-just ways (Chinkin and Paradine 2001, 104). However, both the process of negotiating the DPA and the eventual outcome were 
highly problematic. Women and gender issues were largely excluded from peace negotiations (Chinkin and Paradine 2001, 150). A 'gender-blind' peace agreement emerged that focused on narrowly defined security issues and failed to include pro-active measures to address the conflict's gendered legacy (Chinkin and Paradine 2001; Lithander 2000). The DPA recognized Bosnia's majority ethnic groups-Bosniaks, Croats and Serbs-as 'constituent peoples' and established power-sharing mechanisms and veto powers in key decision-making bodies (Belloni 2004, 336). This reinforced the primacy of ethnicity over other identities (Deiana 2013). BiH was divided into two 'entities'-Republika Srpska (RS) and the Federation of $\mathrm{BiH}$ - plus Brčko District. The entities were granted their own political institutions, and are united by minimal common institutions (Paris 2004, 99). This left BiH with a weak central government beset by deadlock, crises and separatist agendas. War issues remain fiercely politicized, with nationalists seeking to profit from the harms and injustices sustained by survivors (Mlinarević, Isaković and Rees 2015). The transition from war to peace largely relegated women to subordinate positions within the post-war polity, economy and society (Cockburn 2001; Domi 2002; Hasanbegović and Trbonja 2009; Walsh 1998). Power and resources were redistributed (both materially and symbolically) in a manner that was far from gender-just. The differential impact of the conflict on women was inadequately addressed, and the priorities of conflict-affected women largely overlooked (Lithander 2000).

Judicial mechanisms were initially tasked with 'dealing with the past' in BiH. Prosecutions of international crimes have taken place at the International Criminal Tribunal for the Former Yugoslavia (ICTY) and across $\mathrm{BiH}$ - at the state level within the War Crimes Chamber of the State Court of $\mathrm{BiH}$ (WCC), and local courts across the Federation, RS and Brčko District. Criminal trials have created opportunities for some survivors to achieve public recognition of their suffering, bring 'closure', confront perpetrators, honour the memory of those who suffered similar atrocities, and ultimately see perpetrators held accountable (Mertus 2004, 111-112). Notably, significant steps were taken to secure witness testimony, particularly from survivors of sexual violence, through support and protection measures that have enabled their recognition and representation. ${ }^{13}$

However, there have been relatively few prosecutions for sexual violence offences in comparison with their prevalence during the war. ${ }^{14}$ Retributive justice is criticized for producing lenient sentences, and inadequate codification under domestic criminal legislation which contributes towards impunity (TRIAL 2015). Concerns have also been raised regarding the adequacy of witness protection and support. ${ }^{15}$ Although some survivors have found relief and satisfaction through testifying and have relished the opportunity to confront perpetrators in court, many have found testifying to be a stressful and re-traumatizing experience (Mischkowski and Mlinarević 2009, 50-64). Witnesses are also constrained by rules of evidence and procedure, which prevent survivors from narrating experiences in their own terms (Mertus 2004, 116-118). Legal rules and practices are criticized for (re)producing gendered hierarchies of power, constructing survivors of sexual violence as helpless, feminized victims (Campbell 2007; Mertus 2004) whose suffering symbolizes communal narratives of pain (Franke 2006). These gaps and deficiencies have precluded just recognition, redistribution and representation for many survivors - by failing to acknowledge harms incurred by many victims, satisfy demands for material and symbolic reparations and provide a public platform to voice experiences. ${ }^{16}$ 
It is against this background that women at grassroots level have undertaken vital work to address the war's ongoing legacy and campaign for survivors' rights to justice, truth and reparations to be upheld. While other women's and human rights organizations have worked primarily to improve access to justice provided by courts, ${ }^{17}$ advocates of the Women's Court initiative aimed to expand the meaning of justice by creating a new space for women to voice their experiences, promote empathy and understanding for their past/present suffering, and enable women to become political subjects instead of merely objects of TJ processes. ${ }^{18}$ The organizers aimed to increase the visibility of women's resistance to war, nationalism, militarism and sexism, highlight their contributions to TJ processes, and promote their active participation in peacebuilding. ${ }^{19}$

\section{Gender justice from below: the women's court for the former Yugoslavia}

On 7-10 May 2015, in the Bosnian capital Sarajevo, the non-judicial Women's Court for the former Yugoslavia took place, organized by a coalition of civil society activists and women's organizations. The 'Women's Court-A Feminist Approach to Justice' represented a significant attempt to deliver an alternative, feminist model of justice for women affected by the violent dissolution of the Yugoslav state (Kovačević, Perković, and Zajović 2011). This symbolic 'court' provided a platform for women to narrate their experiences of violence and injustice inflicted during and after the wars in the former Yugoslavia. During the four-day event, 36 women from all Yugoslav successor states (BiH, Croatia, Kosovo, Macedonia, Montenegro, Serbia and Slovenia) publicly testified to an audience of approximately 500 people. They spoke of their experiences of war and post-war transition, the myriad forms of violence endured in public and private spheres, and testified about women's organized resistance to war, nationalism and militarism. The event extended public recognition of women's diverse experiences of victimization, trauma and loss, yet also highlighted their capacity to demonstrate agency and resistance.

\section{The women's court: concept and organization}

The Women's Court was inspired by 'a global movement that seeks to relook at rights and other notions of justice from the lives and life visions of women-particularly from the global South' (El Taller, cited in Duhacek 2015, 160). The concept originates from the work of the Asian Women's Human Rights Council, which has organized several courts in the Asia Pacific region since 1992. Its sister organization, El Taller International, has taken these courts across the globe (Kumar 2005, 192-194). ${ }^{20}$ Women's Courts are organized by women's groups at local, regional and/or international levels, through a preparatory process that aims to be both inclusive and democratic, and which deploys educational activities, artistic events and/or working groups (Kovačević, Perković, and Zajović 2011, 16-17). At the international level, financial support was received from international women's funds including the Global Fund for Women, Mama Cash, Urgent Action Fund and the regional Reconstruction Women's Fund (Žene u Crnom 2012a, 6). At the regional level, the preparatory process was led by Women in Black Belgrade (WiB), on behalf of a Regional Organizing Board composed of members of organizations from across the post-Yugoslav region. ${ }^{21} \mathrm{BiH}$ was represented first by Memnuna Zvizdić (Žena Ženama), and later by Jadranka Milićević (Foundation CURE) and Stanojka Tešić (Forum Žena) - these activists were nominated as individuals by $\mathrm{BiH}$ activists to be the 'voice and ears of $\mathrm{BiH}^{2} .{ }^{22}$ The Mothers of the Enclaves of Srebrenica and Žepa were also invited to be Board members by $\mathrm{WiB}^{23}$ At the $\mathrm{BiH}$ level, four partner organizations promoted and implemented the 
initiative-Foundation CURE in Sarajevo, the Centre for Legal Assistance for Women in Zenica, Budućnost in Modriča and Forum Žena in Bratunac. These organizations, located in both the Federation of $\mathrm{BiH}$ and RS, undertook street actions, workshops and public presentations to promote public awareness of the initiative within $\mathrm{BiH}$. They also travelled to local communities to work with potential witnesses and their supporters to prepare them for testifying. Their work was supplemented by the activities of three other organizations in BiH-Lara in Bijeljina, HO Horizonti in Tuzla and Most in Višegrad - which organized promotional events in their local communities to inform the public about the Women's Court concept and approach to justice. All seven are long-established organizations that work on promoting gender equality and tackling gender-based violence within $\mathrm{BiH}$, and form part of an existing network of Bosnian women's NGOs supported by the Swedish NGO Kvinna til Kvinna.

Each of the Courts displays a different ethos and emphasis, depending on the objectives of the organizers (Kumar n.d.). However, each one is connected by a methodology that aims to: "weave together the objective reality (through analyses of the issues) with the subjective testimonies of the women; the personal with the political; the logical with the lyrical' (Kumar 2005, 190). The Sarajevo Court featured five thematic panels: (i) 'war against civilians' (spotlighting militaristic/ethnic/gender-based forms of violence); (ii) 'women's bodies-a battlefield' (focusing on sexual violence in conflict); (iii) 'militaristic violence and women's resistance'; (iv) 'ethnic violence'; and (v) '(un)declared war' (centred on social and economic violence and women's resistance). Women's Courts centre on public hearings featuring personal testimonies of gender violence and injustice. Testimonies are received by a jury whose role is to reflect upon, analyse and respond, as well as mediate between the witnesses and the international human rights community (Kumar 2005, 190). Jury members are selected on the basis of their knowledge, expertise and status - 'whose words carry a significant weight in the world'. ${ }^{24}$ In Sarajevo, an International Judicial Council was formed, comprised of highly regarded legal scholars and feminist activists from the region and beyond. ${ }^{25}$ Firstperson testimonies from survivors ${ }^{26}$ were followed by testimonies from expert witnesses who situated personal experiences of violence within their historical, political and socio-economic contexts. ${ }^{27}$ This highlighted how social structures such as ethnicity, gender, class and sexuality enabled violations to occur. ${ }^{28}$

Aesthetics are also a significant feature of Women's Courts, with poetry, dancing, handicrafts, theatre performances and other artistic expressions often deployed to convey
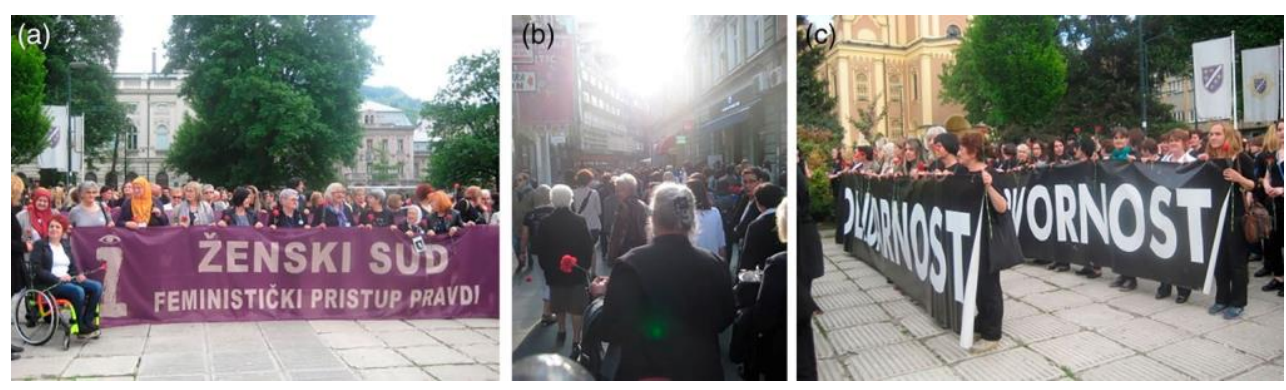

Figure 1. 'Women Together for a Just Peace' street performance, 7 May 2015 () Author. 
experiences of suffering and resistance (Kovačević, Perković, and Zajović 2011, 18). The Sarajevo Court featured a number of these alternative commemorative practices which aim to open up space for public debate on the wartime past (Fridman 2014), and to create a sense of unity, collective identity and solidarity among participants (Bilić 2012). The event opened with a street performance, entitled Women Together for a Just Peace. Women gathered at Liberation Square (Trg Oslobođenja), displaying banners ('solidarity', 'responsibility', 'remembrance'), before walking through the city centre. They carried red carnations, flowers often used to celebrate International Women's Day and to symbolize the working classes during Yugoslav era on occasions such as International Labour Day. Banners hung at the entrance to the event, displaying quotes from witnesses for participants to read on their arrival. Photos of wartime destruction, anti-war demonstrations and commemoration ceremonies were also exhibited, alongside placards naming sites of notorious detention settings, and flags and posters used by women activists at demonstrations and events.

\section{Women's court for the former Yugoslavia as an expression of popular justice}

The Women's Court for the former Yugoslavia can be understood as a form of 'popular justice' in which justice is exercised by individuals and groups from civil society, in a region characterized by functioning domestic law (Merry and Milner 1995, 3). According to Merry and Milner $(1995,4)$, popular justice is typically characterized by:

popular sovereignty, direct governance and control by the people, the capacity of judges to exercise social power autonomously, a minimum level of institutionalization and bureaucratization, nonprofessionalized handling of disputes, and little specialization.

Popular justice mechanisms are relatively informal in nature, deploy non-professional and non-legal language and personnel, and are local in scope and limited in jurisdiction (Merry 1992, 162). The justice dispensed by popular justice mechanisms is:

unofficial (dissociated from state power), noncoercive (dependent on rhetoric rather than force), nonbureaucratic, decentralized, relatively undifferentiated, and non-professional; its substantive and procedural rules are imprecise, unwritten, democratic, flexible, ad hoc, and particularistic. (Abel 1982, 2)
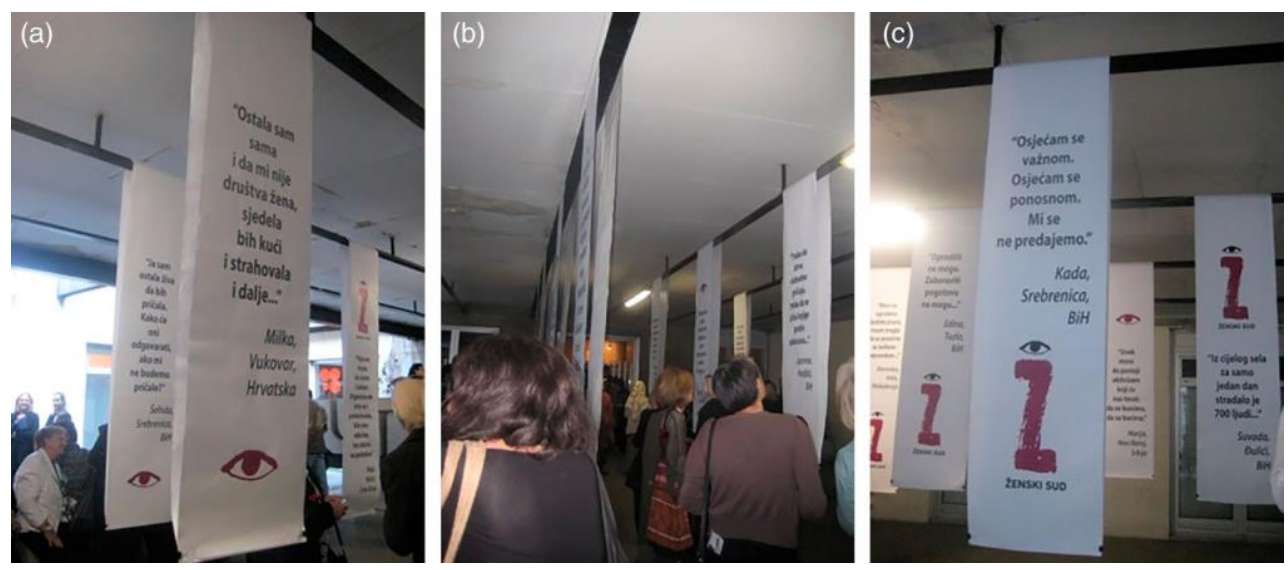

Figure 2. Banners in the entrance to Women's Court, 7-10 May 2015 () Author. 
The Court relied largely on the participation and leadership of lay people rather than legal experts (although legal experts took part as members of the jury). It did not possess an official mandate and coercive instruments to sanction or punish perpetrators of violence. The Court was an ad hoc initiative, tailored to the particular circumstances affecting women in post-Yugoslav countries. However, it also appropriated some of the language, symbols and rituals of the official legal system. For example, it deployed legal terms such as 'witnesses', 'expert witnesses' and 'judicial council', yet concluded with the presentation of preliminary decision and recommendations (rather than a 'judgment') by the Council on the final day. Furthermore, whilst it aimed to provide a restorative rather than retributive form of justice to survivors, the Court also sought to demand accountability, thereby connecting the initiative to both international and domestic courts where war crimes trials are ongoing. It was communitarian in nature, ${ }^{29}$ and expressed the values and norms of women who form a community of peace and feminist activists across the region. The Court also provided continuity with the socialist tradition of popular justice by encouraging victims to take an active role in proceedings; localizing justice by organizing the event in the region as opposed to third countries; and seeking to restore fractured relationships among individuals and communities, without denying the importance of legal remedies. ${ }^{30}$

\section{Assessing the women's court as a feminist model of transitional justice}

The Women's Court aimed to provide a feminist model of transitional justice. It emerged in response to the perceived shortcomings of the top-down, perpetrator-focused model of retributive justice emerging from international and domestic legal institutions which have often failed to recognize and to sanction violence perpetrated against women and other marginalized groups (Kovačević, Perković, and Zajović 2011, 11). ${ }^{31}$ In contrast to criminal tribunals, the Court was a bottom-up initiative springing from activists within civil society, which aspired to address the needs of women survivors of wartime violence and to achieve a restorative (rather than retributive) form of justice that heals both individual victims and the communities in which violence took place (Žene u Crnom 2012b). ${ }^{32}$

\section{Justice as recognition}

The Women's Court was specifically designed to spotlight women's voices and experiences through dedicated public hearings that explored the gendered impact of conflict. This focus brought 'women into view' and exposed the specific challenges they face in (post-) conflict contexts (Ní Aoláin and Rooney 2007, 340). It directly responded to feminist critiques that women's testimonies are often excluded from truth recovery processes, or else tend to focus on violence experienced by family members instead of themselves (Theidon 2007, 457; Ross 2003). One panel was dedicated to the issue of rape and sexual violence, at which four women recounted their experiences. ${ }^{33}$ This was significant given the awareness that such survivors may find it particularly difficult to participate in truth-telling processes. The recognition of rape and sexual violence in post-war justice mechanisms can be a 'mixed blessing' (Buckley-Zistel and Zolkos 2012,10). Women are often reduced to 'targets of one particular crime and construct[ed] as perpetual victims, fixing their social positions and political identities ... as passive, inferior, vulnerable, and in need of (male) protection' (Buckley-Zistel and Zolkos 2012, 10). Yet one striking 
aspect of several sexual violence testimonies was a focus on survivors' active efforts to recover and rebuild their lives. Testimonies of extreme victimization were therefore situated within 'womanly narratives of heroism' (Theidon 2007, 465). Furthermore, although the contributions of expert witnesses highlighted the devastating impact of rape and sexual violence on the physical and psychological wellbeing of victims, they also stressed the agency that survivors demonstrate by battling patriarchal legal frameworks and demanding their rights to justice and reparations. Rather than pathologizing survivors through the sole use of medicalized discourses, they constructed survivors as rights-holders and key agents of justice. Witnesses and experts therefore challenged 'institutionalized patterns of cultural value' that constitute women in general, and SGBV survivors in particular, 'as inferior, excluded, wholly other, or simply invisible' (Fraser 2007, 31).

Beyond sexual violence, the testimonies presented provided a varied account of the harms and losses women endured in wartime. This included the loss of loved ones; torture, detention and sexual violence; enforced disappearances of family members; displacement to refugee and IDP camps; forced mobilization of male relatives; giving birth whilst in flight; and life under siege and in conditions of heightened insecurity. The hearings also highlighted the ongoing impact of war on women's lives. Women recounted battling health problems; managing sudden accession to heads of households; surviving in conditions of insecurity and economic adversity; returning to pre-war homes and communities and fighting to reclaim property, or alternatively remaining displaced and being unwilling/unable to return. Furthermore, following the first and fourth panels on 'war against civilians' and 'ethnic violence', expert witnesses highlighted the importance of hierarchical gender roles, identities and structures of power to the emergence of ethnicized identity politics, militarism and production of violence (particularly perpetrated against women). They also identified the 'continuum of violence' (Valji 2007, 12) and inequality women experience in wartime and peacetime. The final panel on '(un)declared war' placed the spotlight on socioeconomic violence experienced by women as a result of post-war privatization and liberalization processes. This broadened traditional understandings of the range of harms incurred by women from an unduly narrow focus on direct injury and political violence to encompass violations of social and economic rights (e.g. Ní Aoláin and Turner 2007, 254; Bell and O'Rourke 2007, 34). By extending the focus beyond single violations and specific events to highlight wider structures of inequality and ongoing harms, the Court highlighted how women are constituted 'as less-than-full partners' by societal 'status orders' and economic structures in existence before, during and after conflict (Fraser 2007, 28).

Nevertheless, the Women's Court event was restricted in its ability to provide a wideranging and inclusive public account of BiH women's experiences of conflict. As a timebound event, spanning only four days and five panels, it could not hope to achieve a comprehensive account of the gendered harms and injustices of war. This point notwithstanding, there were notable gaps in the recognition and representation of particular forms of violence and of specific groups of conflict-affected women in $\mathrm{BiH}$. First, $\mathrm{BiH}$ testimonies tended to focus on violations experienced by their husbands, sons and male relatives, with the only direct harm presented as sexual violence (Porobić Isaković and Mlinarević 2016, 30). ${ }^{34}$ This familial mode of truth-telling is problematic in extending recognition to women 'as secondary victims rather than as primary agents in a struggle against injustice' (Goldblatt and Meintjes 1998, 8). BiH narratives also focused exclusively on wartime experiences, thereby excluding recognition of pre-war and post-war periods and the gendered structures of inequality that enable gendered violence and discrimination to emerge and endure (Porobić Isaković and Mlinarević 2016, 30-32).

Second, only five of the 36 testimonies centred on sexual violence. ${ }^{35}$ The panel dedi- 
cated to this issue was the smallest of all the panels. It was composed of a relatively narrow range of witnesses (from Kosovo and eastern $\mathrm{BiH}$ ) ${ }^{36}$ whose narratives highlighted experiences of being targeted as Muslim/Bosniak women by Serb men. ${ }^{37}$ Consequently, the Court failed to seize this opportunity to fully challenge ethno-nationalist narratives and related hierarchies of victimhood that dominate discussions of wartime rape within $\mathrm{BiH}$ (see Helms 2013). In addition, the panel focused exclusively on the strategic use of rape by combatants as a tactic or weapon of war-on rape as having 'a systematic, pervasive, or officially orchestrated aspect' (Buss 2009, 149). This theme was emphasized through the panel's title ('women's bodies - a battlefield'). It was also constructed through the narratives of witnesses who testified to being raped in the context of widespread attacks against civilian populations. As sexual violence is often a hidden aspect of war, it was both important and courageous for these women to share their testimonies so that rape and sexual violence is better understood and its ongoing legacy adequately addressed (Goldblatt and Meintjes 1998, 7). ${ }^{38}$ However, this framing meant that other 'rape regimes' that existed during the 1990s conflicts - such as 'opportunistic' rape, rape by family members, sexual exploitation/forced prostitution, and rapes involving victims and perpetrators who do not belong to opposing warring parties (Boesten 2010) — and gendered power relations by which they were enabled remained unrecognized.

Third, all BiH witnesses testified about their first-hand encounters with violence in the Podrinje Valley (eastern $\mathrm{BiH}$ ). This geographically narrow range of testimonies meant that the Court was unable to capture the experiences of women living elsewhere in $\mathrm{BiH}^{39}$ Surprisingly, the Court did not feature testimonies of women from, for example, urban centres such as Sarajevo and Mostar (famous for their pre-war cosmopolitan character), the Bosanska Krajina region (infamous for mass killings, ethnic cleansing and detention camps) or from the town of Tuzla (whose local government resisted ethno-nationalism during the war). This highlights the propensity of truth-telling initiatives to focus on illustrative/exemplary cases, resulting in an entire country being represented as an 'undifferentiated whole' (Arriazza and Roht-Arriaza 2008, 144).

Fourth, the Court failed to capture many other aspects of women's wartime roles and identities, particularly their active participation in the war effort. In $\mathrm{BiH}$, for example, several thousand women volunteered to serve in the national armies and militias, taking on not only support positions but also combatant roles (Hadžiahmić 2011; Kesić 1999, 188). Extending recognition of (ex-)combatant women's experiences could have disrupted traditional metanarratives of war as a masculine endeavour, by revealing how armed forces depend on upon women's labour (Enloe 1983). The Court missed a valuable opportunity to explore the lived realities of women (ex-)combatants who can be considered both as perpetrators and as victims (Coulter 2008), and failed to examine whether post-war peacebuilding processes have met their needs. Ultimately, the focus of the Women's Court on validating the experiences of victims rather than agents of wartime violence meant that it was unable to adequately contend with questions of responsibility, innocence and guilt. Similar to other truth recovery processes, it overlooked the 'ambiguities, mixed motives and shades of grey' that coloured the conflicts in the region (Arriazza and Roht-Arriaza 2008, 153). It failed to adequately explore the 'grey zone' of conflict in which clear-cut distinctions between perpetrators and victims are difficult to maintain (Theidon 2010,100). This highlights the propensity for truth recovery processes to (re)produce dichotomous identities of victims and perpetrators via a victim-centred approach that emphasizes the suffering of innocent civilians' (Theidon 2010, 100). It also underscores the point that alternative/complementary justice mechanisms are not necessarily more inclusive of women's experiences (Ephgrave 2014,3). In the BiH context, this meant that essentialist narratives of women's victimhood 
and lack of complicity and responsibility in processes of violence and oppression (Helms $2013,7)$ remained largely unquestioned.

Ultimately, gender justice requires achieving parity of participation across multiple axes of differentiation (Fraser 2007, 28). With respect to $\mathrm{BiH}$, it requires recognition of the intersection of gender and other structures of identity-including military/civilian status, ethnicity and urban/rural location - and, relatedly, the varied patterns of violence and harms incurred by differentially positioned women. In this regard, the Court largely failed to extend justice as recognition for women in $\mathrm{BiH}^{40}$

\section{Justice as redistribution}

Moreover, the ability of the Women's Court to deliver redistribution of material resources in favour of women survivors is severely limited. Achieving the gender justice envisaged in Fraser's tripartite model requires extensive state-sponsored, collective measures to achieve the significant redistribution of material resources (Durbach and Chappell 2014). It also entails the reversal of neo-liberal marketization policies that prioritize privatization and free-market reform processes over BiH citizens' economic rights and needs (e.g. Donais 2005). Overall, it requires structural transformations geared towards improving the social status of waraffected women.

BiH lacks a state-wide law and comprehensive reparations strategy which would uphold the rights of all survivors to measures of restitution, compensation, rehabilitation, satisfaction and guarantees of non-repetition. ${ }^{41}$ The Criminal Procedures Code of $\mathrm{BiH}$ permits victims to make financial claims, however prosecutors and judges do not utilize this provision in

practice. ${ }^{42}$ Instead, survivors have been instructed that they may take civil action to pursue claims under property law, however the costs of initiating claims are prohibitive in the absence of free legal aid (TRIAL 2011, 37-38).

Entity-level legislation does enable survivors of wartime rape to be recognized as 'civilian victims of war', entitling them to financial and material support (see also Hronešová 2016). These laws provide a limited measure of satisfaction since they bestow recognition of the harms suffered by survivors and of the ongoing impact on their lives, and provide limited measures of compensation. However, they are highly problematic because they construct hierarchies of suffering, care and support, and fail to provide effective redress for many survivors of rape and sexual violence. First, disabled war veterans are privileged over civilian victims of war in both the FBiH and the RS-with the latter entitled to significantly lower allowances ( 70 per cent of veterans' allowances) and subject to a higher threshold of harm to qualify for benefits ( 60 per cent rather than 20 per cent bodily damage). This preferential treatment of war veterans, the vast majority of whom are men, is one example of how 'institutionalized, androcentric value patterns' (Fraser 2007, 26) become codified in post-war legislation. 
Second, survivors of rape living in the Federation are privileged over those living in Republika Srpska. Within the Federation, survivors of rape and sexual violence are explicitly recognized as war victims without requiring that they demonstrate physical damage. In Republika Srpska 60 per cent bodily damage must be proven and psychological harms are not considered (TRIAL 2011, 29). Consequently, many survivors are not eligible for assistance. ${ }^{43}$ In addition, survivors in the RS receive a much lower pension, and are not entitled to preferential treatment in employment or to psychological and legal assistance as in the Federation (TRIAL 2011, 43). The low pension available in Republika Srpska is not sufficient to cover the basic needs of survivors. ${ }^{44}$ Such legislation institutionalises sexist maldistribution' by denying survivors the resources required to participate as equals in society (Fraser 2007, 28). It demonstrates how maldistribution is produced through the boundaries of political community, which work to exclude particular groups and individuals from being entitled to make claims for just distribution (Fraser 2005, 7).

Third, there are serious shortcomings in implementation. In the RS, an application deadline of 31 January 2007 was imposed, excluding many who were unable to submit applications in time. ${ }^{45}$ Survivors have also struggled to obtain the necessary medical documentation to support their application. ${ }^{46}$ In the Federation, survivors must provide medical documentation dating no later than 1997 plus a certificate from a relevant NGO. However, many had not obtained medical documentation by $1997 .{ }^{47}$ These examples highlight how the decision-making rules by which claims are debated and adjudicated (Fraser 2005, 7) deny claimants just redistribution. In addition, although civilian victims of war in the Federation can claim priority in the allocation of housing and employment, this is not implemented in practice. ${ }^{48}$ Moreover, many survivors have been unable to access medical and psychological care, which are key aspects of rehabilitation. Some are living in communities where there is limited access to mental health services, and others cannot afford to pay for medicines and healthcare (Amnesty 2009, 52-57).

As a civil society initiative, the Women's Court was not backed by a reparations programme for $\mathrm{BiH}$. It could not respond to resources disparities; however, its proposals for remedies have potential to lay the ground for redistributive change (Stanley 2009, 125). This could range from affirmative redistribution - such as enabling more survivors to access support provided through existing laws on social protection-through to transformative measures - which would enhance women's status in society. ${ }^{49} \mathrm{BiH}$ activists did engage with representatives from state and entity-level ministries, as part of the preparatory process, to push for government endorsement of a Programme for Victims of Wartime Rape, Sexual Abuse and Torture and their Families in Bosnia-Herzegovina. ${ }^{50}$ This programme, drafted in 2012, is designed to address the shortcomings of existing policies and practices. It aims to secure equal access to justice and reparations, and to raise public awareness of the issues facing survivors. ${ }^{51}$ The programme awaits approval by state and entity-level governments, but remains delayed by ongoing political deadlock. This demonstrates the obstacles to the 'trickle-up' effect of civil society initiatives, particularly in deeply divided societies where political elites continue to propagate division and ethno-nationalist narratives. Furthermore, the preliminary decision and recommendations issued on the final day of the Court called on governments in the region to implement policies of transformative redistribution (RakićVodinelić et al. 2015). These include full disarmament and redirection of military spending into social justice programmes; reversal of privatization processes and prioritization of social justice; and provision of transformative reparations and redress. At the present time, however, it seems highly unlikely that the international organizations involved in peace implementation will roll back their privatization and liberalization agendas, increase 
spending on social justice, or promote disarmament over the pursuit of defence reform and NATO membership.

\section{Justice as representation}

The Women's Court had potential to expand the participation and representation of survivors in TJ processes - to address the 'political dimension of representation' (Fraser 2005, 73) by widening 'who is included in ... the circle of those entitled' to recognition and redistribution (Fraser 2005, 75). One key purpose was to 'listen to women survivors, and to those that resisted violence, that is to hear the voices of survivors' (Corinne Kumar, quoted in Chinkin 2006, 212). The Courts are designed to open up 'a safe place' for women to voice their personal experiences of violence and injustice (Corinne Kumar, quoted in Chinkin 2006, 212). To encourage participation, women's organizations worked on sensibilizing their local communities about the initiative, through seminars, training workshops, public presentations, film screenings, street actions, and the dissemination of newsletters, flyers and other printed materials, etc. ${ }^{52}$ Activists then reached out to selected survivors, introducing them to the Women's Court model through workshops, providing individual and group therapies to help potential witnesses to come to terms with their experiences and prepare them for testifying. Training was also provided to support persons tasked with providing practical and moral support to witnesses. $^{53}$

However, there were a number of factors that hindered BiH survivor participation. First, work with survivors in $\mathrm{BiH}$ was undertaken over a short timescale (over eight months from January to August 2014) and small budget to cover costs of travel and therapy sessions. ${ }^{54}$ One activist noted her regret that the initiative could only offer short-term therapy (five faceto-face sessions and then over-the-phone sessions) when in fact some survivors required longer-term support, and that more survivors were not able to participate due to these constraints. ${ }^{55}$

Second, the perception that the Women's Court was not a neutral initiative appears to have impeded participation by $\mathrm{BiH}$ survivors. Within $\mathrm{BiH}$, the lead organization, WiB, is noted for its work with individuals and communities who were victims of crimes committed by Serbian forces in 'their name'. ${ }^{56}$ Perceptions that the initiative was partial in favour of 'Bosniak' survivors and against 'Serb' survivors in particular were reinforced by the decision by WiB to select the Mothers of Srebrenica association as a Regional Board member. ${ }^{57}$ The screening of promotional materials, which featured testimonies of survivors targeted by Bosnian Serb forces, to women in communities which are mainly Bosnian Serb, was also problematic. This issue was flagged by activists from organizations within the RS, but did not lead to changes in outreach. ${ }^{58}$ Furthermore, the Court received negative press in the RS, with veterans' organizations issuing several statements condemning the initiative. ${ }^{59}$ The lead-up to the Women's Court coincided with RS authorities beginning to shift attention to the situation of survivors of sexual violence in the RS, which led to a focus on the victimization of 'Serb' women as 'invisible victims' and excluded non-Serb women living in the RS. ${ }^{60}$ Against this background of renewed politicization and nationalist rhetoric, it is likely that survivors also made their own pragmatic decisions regarding whether to engage with the process. 
Third, as noted above, there were relatively few testimonies on sexual violence in comparison to other forms of violence. ${ }^{61}$ There are several reasons why women may choose not to testify on this topic. Goldblatt and Meintjes (1998, 10-13) highlight as key constraints: (i) the secondary status of women in society and the resultant failure to recognize sexual violence as political; (ii) the devaluation of experiences of women survivors, particularly of sexual violations that did not involve penetration; (iii) social stigma; (iv) the desire for privacy rather than public exposure; (v) self-blame; (vi) reluctance to revisit traumatic experiences; and (vii) political loyalties which result in survivors of 'intra-group' rape in particular reluctant to testify. In the $\mathrm{BiH}$ context, public testimony is also impeded by deep politicization and exploitation of the issue, with nationalist elites often 'seek[ing] to profit from a narrative of the atrocities committed by others to "their women" (Mlinarević, Isaković, and Rees 2015). Furthermore, many survivors have over the years provided statements to numerous international fact-finding missions, journalists and human rights NGOs. Yet their experiences were frequently manipulated by political elites for wartime propaganda purposes (Benderly 1997, 65), ${ }^{62}$ while others found themselves publicly exposed by journalists who ignored their requests for anonymity, ${ }^{63}$ resulting in survivors experiencing a violent loss of control over the representation of their personal experiences.

\section{Conclusion}

This article has highlighted the centrality of gender justice to post-conflict peacebuilding. It has extended Nancy Fraser's tripartite framework to peacebuilding contexts, and advanced notions of recognition, redistribution and representation as crucial components of genderjust peace. Fraser's trivalent model offers a powerful analytical tool for exploring the varied policies, practices and outcomes of peacebuilding interventions. It renders visible the gendered modes of exclusion, marginalization and inequality that are frequently constructed in post-conflict settings. The framework also provides crucial principles, concepts and strategies which can guide the design and implementation of gender justice initiatives. It is therefore a powerful resource for evaluating peace.

Despite the recent turn in critical peace and conflict studies to study everyday resistance and hybrid forms of peace (Richmond and Mitchell 2011; Mac Ginty 2011), critical peacebuilding scholars have failed to explore local expressions of gendered agency and resistance that emerge in response to international peacebuilding interventions (O'Reilly

2013, 58). The gendered nature of contemporary peacebuilding, and the responses of women-centred groups and movements, remain largely overlooked (see e.g. McLeod 2015; O'Reilly 2012). Visions of peace and justice articulated by women in post-conflict settings are almost entirely missing from critical analyses of international peacebuilding, despite their insistence on bottom-up theorizing. This article has addressed this gap by providing an innovative theoretical framework and novel empirical insights into the local responses and resistances generated by international peacebuilding. It has advanced feminist theory as a significant avenue of analysis for critical peace and conflict studies scholarship.

The case study presented, the Women's Court for the former Yugoslavia, has highlighted both the positive contributions and potential limitations of informal truth-telling projects. By opening up a new space for women to consider how they have in various 
ways and to differing degrees been victimized by and/or been able to resist violence, the Court hoped to achieve gender justice and redress for women affected by armed conflict. The initiative placed women at the centre of $\mathrm{TJ}$ as a process, and aimed to empower women to become agents of social and political change. The testimonies presented by survivors provided valuable insights into the gendered impact of wartime violence and transition from war to peace, into the legacies of pain, loss and injury, but also of the forms of agency that emerge in the aftermath of trauma. Yet the Court struggled to achieve recognition and representation of particular communities of survivors and categories of harm. Its 'bottomup' nature and focus on the micro-level means it will struggle to ensure that its efforts 'trickle up' to achieve transformative change at the macro-level, particularly in the area of redistributive justice.

\section{Notes}

1. Seven subsequent WPS resolutions were adopted by UN Security Council: 1820, 1888, 1889, 1960, 2106, 2122 and 2242.

2. I deploy the term SGBV to denote 'gendered and sexualised forms of harm experienced by women and men in armed conflict', while recognizing that 'women experience wartime violence in ways particular to them as women' (Buss 2011, 413). These modes of violence- including rape, forced enlistment and sex-selective massacres-(re)produce gender roles, identities and hierarchies of power (see Carpenter 2006).

3. Whilst international criminal tribunals increasingly prosecute SGBV, they are criticized for excluding or undermining women's experiences of violence (Ní Aoláin and O'Rourke 2010; Buckley-Zistel and Stanley 2012), through limited interpretations of harm and problematic practices of cross-examination (Campbell 2007; Mertus 2004).

4. Examples include establishing women's hearings, dedicated gender units, gender quotas for commissioners and staff, and specialized witness protection and support; building partnerships with local and international women's organizations; and constructing 'gender-responsive' mandates that are inclusive of women and sensitive to gender-based violence (Theidon 2007, 457; Valji 2010, 9-13).

5. Women's organizations have organized dozens of women's courts and tribunals across the world, with themes ranging from sexual violence, to human trafficking, and the rights of indigenous women. Key examples include the Women's International War Crimes Tribunal on Japan's Military Sexual Slavery (Tokyo, 2000) and the Global Tribunal on Violations of Women's Human Rights (Vienna, 1993).

6. I thank Kirsten Campbell for drawing this to my attention.

7. The arguments presented in this article derive from a detailed investigation into the modes of gendered agency in post-war peacebuilding processes (see O'Reilly forthcoming).

8. This paper is a part of a broader research project on gender and transitional justice in $\mathrm{BiH}$ for which my interview sample included over 100 activists in $\mathrm{BiH}$ and one in Serbia, around 15 of whom have at some point been associated with the Women's Court initiative. Data collection was conducted in April-November 2011, March-June 2012, May, June and September 2014, and in April, May, July, September and October 2015, narrative interviews lasting between 30 minutes and three hours. All participants were interviewed face-to-face, and the majority of interviews were conducted in Bosnian/Croatian/Serbian languages with the aid of an interpreter. I also participated as an observer at the Women's Court event (May 2015), and associated conference (June 2014) and workshop (November 2011), all held in Sarajevo during my fieldwork. Interviewees were asked whether they would like the information they shared to be fully attributed to them or partially/fully anonymous. I respect their choices regarding anonymity/attribution. However, in some instances, I have omitted names and places in order to provide anonymity to women and organizations whose 
statements might be interpreted negatively given the political instability that continues to exist in $\mathrm{BiH}$.

9. E.g. at the time of writing, discussions are ongoing regarding the publication of a book of testimonies, production of documentary film and organization of ongoing support to witnesses.

10. E.g. McKay $(2000,561)$ regards gender justice as ensuring that post-war peacebuilding and TJ processes 'are equitable, not privileged by and for men, and ... acknowledge the ways in which women uniquely experience harm'. Spees $(2004,9)$ defines it as 'the protection and promotion of civil, political, economic and social rights on the basis of gender equality'.

11. Due to space constraints, this section cannot capture the expanding literature on understanding SGBV in conflict. For an overview, please see e.g. Baaz and Stern (2009).

12. For an overview of debates regarding the causes of Yugoslavia's dissolution, see Cohen and Dragović-Soso (2008). On the war in Bosnia, see Woodward (1995).

13. See in particular Rules 34(A), 69,75 and 96 of the ICTY's Rules of Procedure and Evidence, available at http://www.icty.org/

14. At the ICTY, 78 individuals (48 per cent of the 161 total accused persons) have had acts of sexual violence included in ICTY indictments as of mid-2013. Of these, 30 were convicted. The WCC had tried 71 individuals and convicted 33 by 2013. Criminal proceedings before the courts of the Federation, RS and Brčko District has resulted in 45 defendants and 34 convictions by 2014. ICTY, Infographics: ICTY Facts \& Figures, available at http://www.icty.org/sid/ 10586 (last accessed 30 May 2016); OSCE (2014, 2015).

15. This view was expressed at the Track Impunity Always (TRIAL) and ICTY public roundtable I attended on 17 May 2012, through presentations made by representatives of local Prosecutor's Offices.

16. This view was expressed by many interviewees I spoke to throughout my fieldwork.

17. For example, the international advocacy NGO TRIAL (Track Impunity Always) has helped survivors obtain justice for crimes of sexual violence through strategic litigation before domestic authorities and international human rights bodies. See https://trialinternational.org/countriespost/bosnia-herzegovina/ (accessed 19 April 2016).

18. Women in Black, presentation at Women's Court workshop held in Sarajevo, November 2011.

19. Staša Zajović, Women in Black, Personal interview, Belgrade, 8 May 2012.

20. The World Court of Women against War, and for Peace, held in Cape Town in 2001, was particularly significant because it featured several women from the former Yugoslavia. Bosnian activist Memnuna Zvizdić (Women to Women, Sarajevo), was a member of the International Coordination Committee. Žarana Papić, a prominent feminist and member of Women in Black Belgrade (WiB), was one of five speakers on the Opening Panel. Two women from Prijedor, $\mathrm{BiH}$, testified at the event: Nusreta Sivac spoke of surviving wartime rape; Mejra Dautović testified about losing two children and being displaced from her hometown (Kumar 2001). Their testimonies featured in promotional films for the 2015 Women's Court. Mejra Dautović, Personal interview, Bihać, 24 April 2012.

21. The event was organized by a Regional Steering Board, featuring activists from the organizations: Mothers of Srebrenica and Žepa enclaves and Foundation CURE (BiH); Centre for Women Studies and ROSA - Centre for Women War Victims (Croatia); Kosovo Women's Network; National Council for Gender Equality (Macedonia); Anima (Montenegro); Women's Lobby Slovenia; and Women's Studies (University of Belgrade) and Women in Black (both from Serbia). More information is available at http://www.zenskisud.org.

22. Confidential Source, Personal interview, BiH, April 2015.

23. The organizations involved in establishing and implementing the initiative and their degrees of involvement changed over time. Hence it proved difficult to gain accurate information regarding the organization process. I acknowledge that this synopsis is therefore a simplified version.

24. Official website of the Women's Court for the Former Yugoslavia, 'Methodology of Work', http://www.zenskisud.org/en/Metodologija.html (accessed 2 April 2015).

25. These are: Vesna Rakić-Vodinelić, Serbia; Charlotte Bunch, USA; Gorana Mlinarević, BiH; Latinka Perovic, Serbia; Kirsten Campbell, UK; Dianne Otto, Australia; and Vesna Teršelič, Croatia. 
26. Notably, all testimonies presented at the Women's Court for the Former Yugoslavia were firstperson testimonies. First-person, advocate and/or joint testimonies have all been used in other Women's Tribunals, as Reilly and Posluszny (2005) point out.

27. These are: Rada Iveković, Vjolca Krasniqi, Renata Jambrešić Kirin, Miroslava Malešević, Snježana Milivojević (Panels 1 and 4); Marijana Senjak and Gabi Mischkowski (Panel 2); Staša Zajović, Snežana Obrenović and Bojan Aleksov (Panel 3); Tanja Đurić Kuzmanović and Senka Rastoder (Panel 5).

28. This is a key aspect of Women's Court methodology. See official website of the Women's Court for the Former Yugoslavia, 'Methodology of Work', http://www.zenskisud.org/en/ Metodologija.html (accessed 2 April 2015).

29. Merry $(1995,40)$ identifies four main cultural traditions of popular justice that have emerged in the twentieth century: reformist, socialist, communitarian and anarchic.

30. These are some of the key characteristics of the socialist 'self-management courts' created by the 1974 Constitution of SFRY, as outlined by Hayden (1990). None of my respondents highlighted the 'self-management courts' as inspiration for the recent initiative. The Court's continuity with the socialist model of popular justice is striking but appears largely unintended.

31. I should clarify that criminal trials are also viewed as important sources of recognition by survivors of SGBV in BiH, as highlighted by many interviewees. The Women's Court should be viewed as a complementary rather than strictly alternative model of justice for $\mathrm{BiH}$.

32. It is important however to point out that women's wartime activism demanding prosecution of sexual violence was crucial to the establishment of the ICTY (see e.g. Mertus 2008).

33. In addition, another witness testified to her experience of sexual violence during Panel 4 ('ethnic violence').

34. Testimonies from other post-Yugoslav countries recounted other direct harms incurred by women including, for example, the experience of being 'erased' (e.g. stripped of citizenship/ legal status) following Slovenia's declaration of independence in 1991 (Slovenia); and violent and discriminatory processes of post-war privatization (Macedonia, Montenegro, Serbia).

35. I refer here to all four testimonies on Panel 2 ('women's bodies - a battlefield') and one testimony from Panel 4 ('ethnic violence').

36. This point was mentioned by other audience members at the event.

37. The sole exception was the testimony of one woman from Croatia who was raped by a paramilitary group, and was targeted on the basis of her identity as a member of the Serb minority. However she was included in Panel 4 rather than 2.

38. Importantly, women's courage and agency in testifying and engaging in struggles for justice was highlighted by the expert statements and the preliminary decision and recommendations delivered by the Judicial Council.

39. Notably, witnesses from $\mathrm{BiH}$ suggested before the event that the range of $\mathrm{BiH}$ witnesses should be expanded to include women from other regions and towns which do not receive the same degree of public attention as Srebrenica and Podrinja Valley.

Kadefa Rizvanović, Vice-President of Women of Podrinja Association, Personal interview, Ilidža, October 2015.

40. In this regard I diverge from Clark's (2016) view that the Women's Court successfully delivered justice as recognition.

41. These are the key measures of reparations outlined in the UN Basic Principles and Guidelines on the Right to a Remedy and Reparation for Victims of Gross Violations of International Human Rights Law and Serious Violations of International Humanitarian Law (UN 2005).

42. Human Rights Council, A/HRC/11/6/Add.3 (2013), paragraph 94.

43. Lejla Mamut, Human Rights Coordinator, TRIAL, Personal interview, Sarajevo, 13 April 2011.

44. This point was raised during the consultation meeting I attended in Prijedor (RS).

45. This deadline excluded for example those living outside $\mathrm{BiH}$, those without necessary documentation, those who were unaware of the law's existence and those whose health problems prevented them from making claims.

46. Dragiša Andrić, Višegrad Camp Detainees Association, Personal interview, Višegrad, 2 May 2012. 
47. Alisa Muratčauš, Association of Concentration Camp Survivors, Canton Sarajevo, Personal interview, Sarajevo, 21 October 2011.

48. This point was raised during a BiH Ministry of Human Rights and Refugees consultation meeting.

49. For examples of possible transformative measures, please see Porobić Isaković et al. (2016), outlining a concept and framework for the development of a gender-sensitive reparations programme for civilian war victims in $\mathrm{BiH}$.

50. Confidential source, Personal interview, BiH, May 2015. Notably, the RS government refused to receive visits from these organizations.

51. In 2012 I attended several consultative meetings organized by the BiH Ministry for Human Rights and Refugees on the Draft Programme across BiH.

52. Confidential source, Personal interview, BiH, April 2015.

53. Confidential source, Personal interview, BiH, April 2015.

54. In contrast, work with survivors was undertaken on a longer-term basis in other countries (e.g. Serbia and Croatia).

55. Confidential source, Personal interview, BiH, April 2015. The devastating floods that hit $\mathrm{BiH}$ in May 2014 also impeded this preparatory work, with some survivors having to focus on immediate existential needs.

56. McLeod $(2015,107)$ notes that the belief that the Serbian state and society should accept responsibility for war crimes committed during the 1990s conflicts is an 'integral value' of WiB activists.

57. Confidential source, Personal interview, BiH, May 2015.

58. Confidential source, Personal interview, BiH, May 2015.

59. Confidential source, Personal interview, BiH, April 2015.

60. In April 2015, politicians in the RS National Assembly discussed and adopted findings and recommendations of a study on the position of Serb women, victims of wartime crime of sexual violence in $\mathrm{BiH}$ provided by the RS Gender Center.

61. Although survivors of sexual violence from $\mathrm{BiH}$ participated in the preparatory process, not all chose to publicly testify at the May event. Suvada Selimović and Šaha Hrustić, Association Anima 2005, Personal interview, Đulići, October 2015.

62. Benderly $(1997,65)$ highlights that during the war a 'numbers game' was played-between the European Community, human rights groups, the United Nations, as well as governments in the region-regarding the magnitude and character of wartime rape.

63. This was pointed out at the consultation meetings I attended on the topic of wartime rape and sexual violence organized by BiH Ministry of Human Rights and Refugees in 2012.

\section{Acknowledgements}

I thank Catherine Baker, Jelena Obradovic-Wochnik, Gorana Mlinarević and Kirsten Campbell for their very helpful comments on earlier versions of this paper. I also thank Elma Demir and Jasenka Ferizović for ongoing discussions on gender justice initiatives in BiH, and Una Tokmačić for interpretation and research assistance.

\section{Disclosure Statement}

No potential conflict of interest was reported by the author.

\section{Funding}

This work was supported by the UK Economic and Social Research Council [grant number ES/ G013993/1], British Academy ('Gendered Agency in War and Peace' project) and European Research Council ('Gender of Justice' project) [grant number 313626]. 


\section{Notes on contributor}

Maria O'Reilly is a Post-Doctoral Researcher in Sociology at Goldsmiths, University of London, currently researching the gendered impact of DDR policies in post-conflict Bosnia \& Herzegovina, and women combatants' experiences of reintegration. She has also researched gender and transitional justice issues, and her book, Gendered Agency in War and Peace: Gender Justice and Women's Activism in PostConflict Bosnia-Herzegovina is forthcoming. (m.oreilly@gold.ac.uk)

\section{References}

Abel, Richard L. 1982. "Introduction." In The Politics of Informal Justice, Vol. 2, edited by Richard L. Abel, 1-16. New York: Academic Press.

Amnesty International. 2009. Whose Justice? The Women of Bosnia and Herzegovina Are Still Waiting. London: Amnesty International.

Anderson, Miriam. 2012. "Gender and Peacemaking: Women's Rights in Contemporary Peace Agreements." In Peacemaking: From Practice to Theory, edited by S. A. Nan, Z. C. Mampilly, and A. Bartoli, 344-377. Santa Barbara, California: Praeger.

Arnould, Valerie. 2016. "Transitional Justice in Peacebuilding: Dynamics of Contestation in the DRC." Journal of Intervention and Statebuilding 10 (3): 1-18.

Aroussi, Sahla. 2011. "Women, Peace and Security': Addressing Accountability for Wartime Sexual Violence." International Feminist Journal of Politics 13 (4): 576-593.

Arriazza, Laura, and Naomi Roht-Arriaza. 2008. "Social Repair at the Local Level: The Case of Guatemala." In Transitional Justice from Below: Grassroots Activism and the Struggle for Change, edited by Kieran McEvoy and Lorna McGregor, 143-166. Oxford: Hart Publications.

Askin, Kelly D. 2001. "Comfort Women-Shifting Shame and Stigma from Victims to Victimizers." International Criminal Law Review 1 (1): 5-32.

Baaz, Maria Eriksson, and Maria Stern. 2009. "Why Do Soldiers Rape? Masculinity, Violence, and Sexuality in the Armed Forces in the Congo (DRC)." International Studies Quarterly 53 (2): 495-518.

Bell, Christine, and Catherine O'Rourke. 2007. "Does Feminism Need a Theory of Transitional Justice? An Introductory Essay." International Journal of Transitional Justice 1 (1): 23-44.

Bell, Christine, and Catherine O'Rourke. 2010. "Peace Agreements or Pieces of Paper? The Impact of UNSC Resolution 1325 on Peace Processes and their Agreements." International and Comparative Law Quarterly 59 (4): 941-980.

Belloni, Roberto. 2004. "Peacebuilding and Consociational Electoral Engineering in Bosnia and Herzegovina." International Peacekeeping 11 (2): 334-353.

Benderly, Jill. 1997. "Rape, Feminism and Nationalism in the War in Yugoslav Successor States." In Feminist Nationalism, edited by Lois A. West, 59-72. London: Routledge.

Bilić, Bojan. 2012. "Not in our Name: Collective Identity of the Serbian Women in Black." Nationalities Papers 40 (4): 607-623.

Boesten, Jelke. 2010. "Analyzing Rape Regimes at the Interface of War and Peace in Peru." International Journal of Transitional Justice 4 (1): 110-129.

Bracewell, Wendy. 1996. "Women, Motherhood, and Contemporary Serbian Nationalism." Women's Studies International Forum 19 (1/2): 25-33.

Buckley-Zistel, Susanne, and Ruth Stanley, eds. 2012. Gender in Transitional Justice. Basingstoke: Palgrave MacMillan.

Buckley-Zistel, Susanne, and Magdalena Zolkos. 2012. "Introduction: Gender in Transitional Justice." In Gender in Transitional Justice, edited by Susanne Buckley-Zistel and Ruth Stanley, 1-33. Basingstoke: Palgrave MacMillan.

Buss, Doris E. 2009. "Rethinking 'Rape as a Weapon of War'." Feminist Legal Studies 17 (2): 145-163. Buss, Doris. 2011. "Performing Legal Order: Some Feminist Thoughts on International Criminal Law." International Criminal Law Review 11 (3): 409-423.

Campbell, Kirsten. 2007. "The Gender of Transitional Justice: Law, Sexual Violence and the International Criminal Tribunal for the Former Yugoslavia." International Journal of Transitional Justice 1 (3): 411-431. 
Caprioli, Mary. 2005. "Primed for Violence: The Role of Gender Inequality in Predicting Internal Conflict." International Studies Quarterly 49 (2): 161-178.

Carpenter, R. Charli. 2006. "Recognizing Gender-Based Violence against Civilian Men and Boys in Conflict Situations." Security Dialogue 37 (1): 83-103.

Chinkin, Christine. 2006. "People's Tribunals: Legitimate or Rough Justice." Windsor Yearbook Access to Justice 24 (2): 201-220.

Chinkin, Christine, and Kate Paradine. 2001. "Vision and Reality: Democracy and Citizenship of Women in the Dayton Peace Accords." Yale Journal of International Law 26: 103-178.

Clark, Janine Natalya. 2016. "Transitional Justice as Recognition: An Analysis of the Women's Court in Sarajevo." International Journal of Transitional Justice 10 (1): 67-87.

Cockburn, Cynthia. 2001. Women Organizing for Change: A Study of Women's Local Integrative Organizations and the Pursuit of Democracy in Bosnia-Herzegovina. Zenica: Medica.

Cohen, Lenard J., and Jasna Dragović-Soso, eds. 2008. State Collapse in South-Eastern Europe: New Perspectives on Yugoslavia's Disintegration. West Lafayette, IN: Purdue University Press.

Cohn, Carol. 2008. 'Mainstreaming Gender in UN Security Policy: A Path to Political Transformation?' In Global Governance: Feminist Perspectives, edited by S. Rai and G. Waylen, 185-206. Basingstoke: Palgrave Macmillan.

Coulter, Chris. 2008. "Female fighters in the Sierra Leone war: challenging the assumptions?," Feminist Review 88: 54-73.

Cousens, Elizabeth M., and Charles K. Cater, eds. 2001. Toward Peace in Bosnia: Implementing the Dayton Accords. Boulder, CO: Lynne Rienner.

Crosby, Alison, and M. Brinton Lykes. 2011. "Mayan Women Survivors Speak: The Gendered Relations of Truth Telling in Postwar Guatemala." International Journal of Transitional Justice 5 (3): 456-476.

Deiana, Maria-Andreana. 2013. "Citizenship as (Not) Belonging? Contesting the Replication of Gendered and Ethnicised Exclusions in Post-Dayton Bosnia-Herzegovina." In Beyond Citizenship? Feminism and the Transformation of Belonging, edited by Sasha Roseneil, 184-210. Houndmills:

Palgrave Macmillan.

Dewhirst, Polly, and Amrita Kapur. 2015. The Disappeared and Invisible: Revealing the Enduring Impact of Enforced Disappearances on Women. New York: International Center for Transitional Justice. Domi, Tanya L. 2002. "Advancing Women's Political Rights in Bosnia-Herzegovina." The Harriman Review 14 (1-2): 36-46.

Donais, Timothy. 2005. The Political Economy of Peacebuilding in Post-Dayton Bosnia. Abingdon: Routledge.

Drakulić, Slavenka. 1993. "Women and the New Democracy in the Former Yugoslavia." In Gender Politics and Post-Communism: Reflections from Eastern Europe and the Former Soviet Union, edited by Nanette Funk and Magda Mueller, 123-130. New York: Routledge.

Duhacek, Dasa Gordana. 2015. "The Women's Court: A Feminist Approach to In/Justice." European Journal of Women's Studies 22 (2): 159-176.

Durbach, Andrea, and Louise Chappell. 2014. "Leaving Behind the Age of Impunity." International Feminist Journal of Politics 16 (4): 543-562.

Enloe, Cynthia. 1983. Does Khaki Become You? The Militarization of Wokmen's Lives. London: Pluto Press.

Ephgrave N. 2014. "Women's testimony and collective memory: Lessons from South Africa's TRC and Rwanda's gacaca courts.” European Journal of Women's Studies, DOI: 1350506814547057.

Franke, Katherine M. 2006. "Gendered Subjects of Transitional Justice." Columbia Journal of Gender and Law 15: 813-828.

Fraser, Nancy. 1997. "From Redistribution to Recognition? Dilemmas of Justice in a "Postsocialist' State." In Justice Interruptus: Critical Reflections on the "Postsocialist" Condition, 11-39. New York: Routledge.

Fraser, Nancy. 2000. "Why Overcoming Prejudice is Not Enough: A Rejoinder to Richard Rorty." Critical Horizons 1 (1): 21-28.

Fraser, Nancy. 2003. "Social Justice in the Age of Identity Politics: Redistribution, Recognition, and Participation." In Redistribution or Recognition? A Political-Philosophical Exchange, edited by Nancy Fraser and Axel Honneth, 7-109. London: Verso. 
Fraser, Nancy. 2005. "Reframing Justice in a Globalizing World." New Left Review 36: 1-19.

Fraser, Nancy. 2007. "Feminist Politics in the Age of Recognition: A Two-dimensional Approach to Gender Justice." Studies in Social Justice 1 (1): 23-35.

Fraser, Nancy. 2008. Scales of Justice: Reimagining Political Space in a Globalizing World, 1-38. Cambridge: Polity Press.

Fridman, Orli. 2014. "Alternative Calendars and Memory Work in Serbia: Anti-war Activism after Milošević." Memory Studies 8 (2): 212-226.

Goetz, Anne-Marie. 2007. "Gender Justice, Citizenship, and Entitlements." In Gender Justice, Citizenship, and Development, edited by M. Mukhopadhyay and N. Singh, 15-57. New Delhi: Zubaan.

Goldblatt, Beth, and Sheila Meintjes. 1998. "Dealing with the Aftermath: Sexual Violence and the Truth and Reconciliation Commission." Agenda 13: 7-18.

Hadžiahmić, Lejla. 2011. "Women-combatants in defense of Sarajevo: Agents or Victims," Western Balkans Security Observer-English Edition 19: 36-45.

Hasanbegović, Azra, and Aldijana Trbonja. 2009. Dijagnostički Izvještaj: Pomoć pri izgradnjia mira kroz implementaicju Rezolucije UNSCR 1325 na području Balkana. Mostar: M. Z. C. Mostar and Žena BiH Mostar (Diagnostic Report: Help to Build Peace Through the Implementation of Resolution UNSCR 1325).

Hayden, Robert M. 1990. Social Courts in Theory and Practice: Yugoslav Workers Courts in Comparative Perspective. Philadelphia: University of Pennsylvania Press.

Hayner, Priscilla. 2002. Unspeakable Truths: Confronting State Terror and Atrocity. New York: Routledge.

Helms, Elissa. 2013. Innocence and Victimhood: Gender, Nation, and Women's Activism in Postwar Bosnia-Herzegovina. Madison: University of Wisconsin Press.

Hronesova, Jessie. 2016. "Might Makes Right: Compensatory War-Related Payments in Bosnia and Herzegovina." Journal of Intervention and Statebuilding 10 (3).

ICMP. 2014. Bosnia and Herzegovina Missing Persons from the Armed Conflicts of the 1990s: A Stocktaking. Sarajevo: International Commission on Missing Persons (ICMP).

Kesić, Obrad. 1999. "Women and Gender Imagery in Bosnia: Amazons, Sluts, Victims, Witches and Wombs", in Sabrina P. Ramet, ed., Gender Politics in the Western Balkans: Women, Society, and the Yugoslav Successor States, University Park, P.A.: Pennsylvania State University Press, 187-202. Korač, Maja. 2006. "Gender, Conflict and Peace-building: Lessons from the Conflict in the Former Yugoslavia." Women's Studies International Forum 29: 510-520.

Kovačević, Ljupka, Marija Perković, and Staša Zajović, eds. 2011. Zenski sud: Feministicki pristup pravdi [Women's Court: feminist approach to justice]. Beograd and Kotor: Women in Black and Anima.

Kumar, Corinne. n.d. The Courts of Women: AWHRC and El Taller International. Accessed April 2, 2015. http://www.rutapacifica.org.co/descargas/mdn/pon_CorinneKumar.pdf

Kumar, Corinne. 2001. The World Court of Women Against War, For Peace: A Brief Overview. March 25. Accessed April 1, 2015. http://snellings.telenet.be/womeninblackleuven/world_court_women.htm

Kumar, Corinne. 2005. "South Wind: Towards a New Political Imaginary." In Dialogue and Difference: Feminisms Challenge Globalization, edited by Marguerite R. Waller and Sylvia Marcos, 165-199. Basingstoke: Palgrave Macmillan.

Lai, Daniela. 2016. "Transitional Justice and its Discontents: Socioeconomic Justice in Bosnia and Herzegovina and the Limits of International Intervention." Journal of Intervention and Statebuilding $10(3): 1-21$.

Leatherman, Janie L. 2011. Sexual Violence and Armed Conflict. Cambridge: Polity.

Lithander, Anna. 2000. Engendering the peace process: a gender approach to Dayton-and beyond. Kvinna till kvinna.

MacGinty, Roger. 2011. International Peacebuilding and Local Resistance: Hybrid Forms of Peace. London: Palgrave Macmillan.

Martin, Laura S. 2016. "Practising Normality: An Examination of Unrecognizable Mechanisms in PostConflict Sierra Leone." Journal of Intervention and Statebuilding 10 (3): 1-19.

McKay, Susan. 2000. "Gender Justice and Reconciliation." Women's Studies International Forum 23 (5): 561-570. 
McLeod, Laura. 2015. Gender Politics and Security Discourse: Personal-Political Imaginations and Feminism in "Post-Conflict" Serbia. Abingdon: Routledge.

Meintjes, Sheila, Anu Pillay, and Meredeth Turshen, eds. 2001. The Aftermath: Women in Post-Conflict Transformation. London: Zed Books.

Melander, Erik. 2005. "Gender Equality and Intrastate Armed Conflict." International Studies Quarterly 49 (4): 695-714.

Merry, Sally Engle. 1992. "Popular Justice and the Ideology of Social Transformation." Social \& Legal Studies 1: 161-176.

Merry, Sally Engle. 1995. "Sorting Out Popular Justice." In The Possibility of Popular Justice: A Case Study of Community Mediation in the United States, edited by Sally Engle Merry and Neal Milner, 31-66. Michigan: University of Michigan Press.

Merry, Sally Engle, and Neal Milner. 1995. "Introduction." In The Possibility of Popular Justice: A Case Study of Community Mediation in the United States, edited by Sally Engle Merry and Neal Milner, 1-30. Michigan: University of Michigan Press

Mertus, Julie. 2004. "Shouting from the Bottom of the Well: The Impact of International Trials for Wartime Rape on Women's Agency." International Feminist Journal of Politics 6 (1): 110-128.

Mertus, Julie. 2008. "When Adding Women Matters: Women's Participation in the International Criminal Tribunal for the Former Yugoslavia.” Seton Hall Law Review 38 (4): 1297-1326.

Mischkowski, Gabriella, and Gorana Mlinarević. 2009. The Trouble with Rape Trials-Views of Witnesses, Prosecutors and Judges on Prosecuting Sexualised Violence during the War in the former Yugoslavia. Cologne: Medica Mondiale e.V.

Mlinarević, Gorana, Nela Porobić Isaković, and Madeleine Rees. 2015. "If Women are Left out of Peace Talks." Forced Migration Review 50. http://www.fmreview.org/mlinarevic-isakovic-rees\#sthash. 8 NewBaaL.dpuf

Mostov, Julie. 2002. "Sexing the Nation/Desexing the Body: Politics of National Identity in the Former Yugoslavia." In Gender Ironies of Nationalism, edited by Tamar Mayer, 89-110. London: Routledge.

Ní Aoláin, Fionnuala. 2012. "Advancing Feminist Positioning in the Field of Transitional Justice." International Journal of Transitional Justice 6 (2): 205-228.

Ní Aoláin, Fionnuala, and Catherine O'Rourke. 2010. "Gendered Transitional Justice and the Non-state Actor." In Contested Transitions: Dilemmas of Transitional Justice in Colombia and Comparative Experience, edited by A. Lyons and M. Reed, 115-143. Bogotá: International Center for Transitional Justice.

Ní Aoláin, Fionnuala, and Catherine Turner. 2007. "Gender, Truth and Transition.” UCLA Women's Law Journal 16: 229-279.

Oberschall, Anthony. 2000. "The Manipulation of Ethnicity: From Ethnic Cooperation to Violence and War in Yugoslavia." Ethnic and Racial Studies 23 (6): 982-1001.

O'Reilly, Maria. 2012. "Muscular Interventionism: Gender, Power, and Liberal Peacebuilding in PostConflict Bosnia-Herzegovina." International Feminist Journal of Politics 14 (4): 529-548.

O'Reilly, Maria. 2013. "Gender and Peacebuilding." In Routledge Handbook of Peacebuilding, edited by Roger Mac Ginty, 57-68. Abingdon: Routledge.

O'Reilly, Maria. Forthcoming. Gendered Agency in War and Peace: Gender Justice and Women's Activism in Post-Conflict Bosnia \& Herzegovina. Basingstoke: Palgrave Macmillan.

OSCE. 2014. Combating Impunity for Conflict-Related Sexual Violence in Bosnia and Herzegovina: Progress and Challenges: An Analysis of Criminal Proceedings before the Court of Bosnia and Herzegovina between 2005 and 2013. Sarajevo: Organization for Security Cooperation in Europe (OSCE).

OSCE. 2015. Combating Impunity for Conflict-Related Sexual Violence in Bosnia and Herzegovina: Progress and Challenges: An Analysis of Criminal Proceedings before the Courts of the Federation of Bosnia and Herzegovina, Republika Srpska and Brčko District between 2004 and 2014. Sarajevo: OSCE.

Pankhurst, Donna. 2008. "Introduction." In Gendered Peace: Women's Struggles for Post-War Justice and Reconciliation, edited by Donna Pankhurst, 1-30. New York: Routledge.

Paris, Roland. 2004. At Wars End: Building Peace After Civil Conflict. Cambridge: Cambridge University Press. 
Porobić Isaković, Nela, and Gorana Mlinarević, eds. 2016. Feminist (Re)interpretation of the Dayton Peace Accords. Sarajevo: Women's International League for Peace and Freedom, Bosnia-Syria Initiative. Accessed April 28, 2016. http://womenorganizingforchange.org/Development/wpcontent/uploads/2016/02/DPA-report-FINAL.pdf

Porobić Isaković, Nela, and Gorana Mlinarević, eds. 2016. The Concept and Framework for the Development of a Gender-Sensitive Reparations Program for Civilian Victims of War in Bosnia and Herzegovina. Sarajevo: Women's International League for Peace and Freedom, Bosnia-Syria Initiative. Accessed April 28, 2016. http://womenorganizingforchange.org/en/news/concept- andframework-for-the-development-of-a-gender-sensitive-reparations-program-for-civilian-victi msof-war-in-bosnia-and-herzegovina/

Pratt, Nicola. 2013. "Reconceptualizing Gender, Reinscribing Racial-Sexual Boundaries in International Security: The Case of UN Security Council Resolution 1325 on 'Women, Peace and Security'." International Studies Quarterly 57 (4): 772-783.

Rakić-Vodinelić, Vesna, Charlotte Bunch, Kirsten Campbell, Gorana Mlinarević, Dianne Otto, Latinka Perović, and Vesna Teršelič. 2015. Preliminary Decision, Judicial Council of the Women's Court for the Former Yugoslavia. http://www.zenskisud.org/en/pdf/2015/Womens_Court_Preliminary_ Decision_Judicial_Council_2015.pdf

Reilly, Niamh. 2007. "Seeking Gender Justice in Post-conflict Transitions: Towards a Transformative Women's Human Rights Approach.” International Journal of Law in Context 3 (2): 155-172.

Reilly, Niamh, and Linda Posluszny. 2005. Women Testify: A Planning Guide For Popular Tribunals. New Brunswick, NJ: Center for Women's Global Leadership.

Richmond, Oliver P, and Mitchell, Audra. 2011. Hybrid forms of peace: From everyday agency to postliberalism. Palgrave Macmillan.

Ross, Fiona. 2003. Bearing Witness: Women and the Truth and Reconciliation Commission in South Africa. London: Pluto Press.

Rubio-Marín, Ruth. 2009. "The Gender of Reparations in Transitional Societies." In The Gender of Reparations: Unsettling Sexual Hierarchies While Redressing Human Rights Violations, edited by Ruth Rubio-Marín, 63-120. New York: Cambridge University Press.

Rubio-Marín, Ruth, and Pablo de Greiff. 2007. "Women and Reparations." International Journal of Transitional Justice 1 (3): 318-337.

Spees, Pam. 2004. Gender Justice and Accountability in Peace Support Operations. London: International Alert.

Stanley, Elizabeth. 2009. Torture, Truth and Justice: The Case of Timor-Leste. London: Routledge.

Teitel, Ruti G. 2003. "Transitional Justice Genealogy.” Harvard Human Rights Journal 16: 69-94.

Theidon, Kimberly. 2010. "Histories of Innocence: Postwar Stories in Peru." In Localizing Transitional Justice: Interventions and Priorities After Mass Violence, edited by Rosalind Shaw and Lars Waldorf, 92-110. Stanford, CA: Stanford University Press.

Theidon, Kimberly. 2007 "Gender in Transition: Common Sense, Women, and War," Journal of Human Rights 6 (4): 453-478.

TRIAL (Track Impunity Always). 2011. General Allegation to the Special Rapporteur on Violence against Women, its Causes and Consequences: The Situation of Women Victims of Rape or Other Forms of Sexual Violence During the War in Bosnia and Herzegovina, May.

TRIAL (Track Impunity Always). 2015. Follow-up Report on the Implementation by Bosnia and Herzegovina's of the Recommendations Issued by the Committee on the Elimination of Discrimination against Women in July 2013, CEDAW/C/BIH/CO/4-5.

True, Jacqui. 2012 The Political Economy of Violence against Women. Oxford: Oxford University Press. UN General Assembly. 2005. UN Basic Principles and Guidelines on the Right to a Remedy and

Reparation for Victims of Gross Violations of International Human Rights Law and Serious Violations of International Humanitarian Law, A/RES/60/147.

UN Security Council. 1994. "Letter Dated 24 May 1994 From the Secretary-General to the President of the Security Council," UN Doc. S/1994/674. May 27. Accessed http://daccess-dds-ny.un.org/doc/ UNDOC/GEN/N94/200/60/PDF/N9420060.pdf?OpenElement

Valji, Nahla. 2007. Gender Justice and Reconciliation. Berlin: Friedrich Ebert Stiftung. 
Valji, Nahla. 2010. A Window of Opportunity: Making Transitional Justice Work for Women. New York: UN Women.

Walsh, Martha. 1998. "Mind the Gap: Where Feminist Theory Failed to Meet Development Practice-A Missed Opportunity in Bosnia and Herzegovina." European Journal of Women's Studies 5 (3): 329-343.

Woodward, Susan. 1995. Balkan Tragedy: Chaos and Dissolution after the Cold War. Washington, DC: Brookings Institution Press.

Žene u Crnom. 2012a. Women's Court: Feminist Access to Justice: Report on Implemented Activites, January-December 2011. Belgrade: Women in Black. www.zenskisud.org

Žene u Crnom. 2012b. Zenski Sud: Feministicki Pristup Pravdi, Izvestaj januar 2011.-januar. 2012 (Women's Court: A Feminist Approach to Justice). Beograd: Zene u Crnom. 